\title{
Perspectives of health care professionals on artificial insemination of donor semen: appraising their knowledge and perceptions: a single institution study in Nigeria
}

\author{
Olajide O. Abiola ${ }^{1 *}$, Akinlabi E. Ajao², Olumuyiwa A. Ogunlaja ${ }^{3}$, \\ Sunday O. Adeoye ${ }^{4}$, Ayodeji A. Ojo ${ }^{1}$
}

\begin{abstract}
${ }^{1}$ Urology unit, Department of surgery, Bowen University Teaching Hospital, Ogbomoso, Oyo State, Nigeria ${ }^{2}$ Paediatric surgery unit, Department of surgery, Bowen University Teaching Hospital, Ogbomoso, Oyo State, Nigeria ${ }^{3}$ Department of Obstetrics and Gynaecology, Bowen University Teaching Hospital, Ogbomoso, Oyo State, Nigeria ${ }^{4}$ Department of Family Medicine, Bowen University Teaching Hospital, Ogbomoso, Oyo State, Nigeria
\end{abstract}

Received: 30 May 2019

Accepted: 09 July 2019

\section{*Correspondence:}

Dr. Olajide O. Abiola,

E-mail: ooabiola2015@gmail.com

Copyright: ( $)$ the author(s), publisher and licensee Medip Academy. This is an open-access article distributed under the terms of the Creative Commons Attribution Non-Commercial License, which permits unrestricted non-commercial use, distribution, and reproduction in any medium, provided the original work is properly cited.

\section{ABSTRACT}

Background: Artificial inseminations of donor semen (AID) involve use of heterologous donated semen for conception in infertile couple when indicated or in a single woman desirous of pregnancy. Its practice often requires regulation to address possible ethical and legal issues which may arise. In formulating acceptable guidelines/policies, the perspectives of health professionals and the participants should be considered. Therefore, we sought to explore the knowledge and perception of semen donation for artificial insemination among health professionals.

Methods: A cross sectional study conducted on consenting health workers in a single health institution using a structured questionnaire to assess their knowledge and perception on artificial insemination of donor semen (AID). Descriptive and analytical statistics were applied to the data collected with a statistically significant value of $<0.05$.

Results: One hundred and twenty-one health professionals completed the questionnaires. The mean age of the respondents was $27.58 \pm 5.5 y e a r s$. Sixty of the respondents were males while 61 were females. Eighty-four of the respondents (69.4\%) demonstrated good knowledge of AID while 37 (30.6\%) had poor knowledge. Cadre of health professionals and marital status influenced the knowledge of respondents. Perceptions on AID varied among the respondents mostly influenced by psycho-social factors and possible legal disputes on third party reproductive process. None of the male respondents has ever donated semen and willingness to donate semen was low; with anonymity preferred by the willing donors.

Conclusions: Substantial knowledge gap of AIDS existed among health professionals which were influenced by cadre and marital status. Psycho-social factors and possible legal disputes influenced their perceptions of AID.

Keywords: Artificial insemination of donor semen, Knowledge, Nigeria, Perception, Semen donation

\section{INTRODUCTION}

Infertility is of a great concern to affected couples especially in the setting of African society in which procreation is perceived as the essence of marriage and childlessness is often a dreaded outcome of any marriage. ${ }^{1,2}$ Infertility occurs worldwide with a reported global prevalence rate of $8-12 \%$ among married couples 
with the male factor alone accounting for $30 \%$ of the cases. $^{3}$ However, reports in literature from different regions of Nigeria revealed a slightly higher rate of male factor of $42.4 \%$ and $42.9 \%$ in South East and South West regions of Nigeria respectively; hence, male factor play a prominent role in infertility in Nigeria.,

Male factor infertility may include inability of a man to produce viable spermatozoa in quantity and quality capable of fertilizing an ovum. Such abnormalities which include Azoospermia (no spermatozoa in semen), Oligospermia (low sperm count), asthenozoospermia (reduced sperm motility), teratozoospermia (sperms with abnormal morphology) may be amenable to assisted reproductive techniques. In circumstances of Azoospermia/ severe oligospermia $(\leq 5$ million sperm $/ \mathrm{mL}$ ) where sperm retrieval techniques have failed or in couples that decline other assisted reproductive techniques and in men with absent spermatogenesis, available options for such couples are often artificial insemination from healthy donor semen or child adoption. $^{6}$

Artificial insemination of donor semen (AID) which is also known as Donor semen insemination involves the use of heterologous donated semen from a donor for insemination in a woman. It is often used to achieve conception in infertile couples due to azoospermia, families carrying genetic disease which may be transmitted by the husband's spermatozoa, a Rhesusnegative female partner who is severely Rhesusisoimmunized with a Rhesus- positive male partner, male partner with ejaculatory dysfunction, male partner with sexually transmissible infection that cannot be eradicated or in female without a male partner desirable of pregnancy. ${ }^{7,8}$ It has been reported to be safe and to be an effective therapeutic alternative to adoption for selected couples. ${ }^{9}$

In Nigeria, there are limited reports of practice of AID in management of infertility. This may be related to limited specialist centres/ sperm banks offering donor semen insemination services; coupled with reported low awareness and acceptability of AID by infertile couples. ${ }^{10}$ Also, there is no national semen donation policy/guidelines to regulate and address ethical and legal issues which may be involved in third party reproductive process.

In developing acceptable semen donation policy/guidelines for a population, it is important to incorporate the participants-recipient, the donors, the offspring and the health professionals perspectives. ${ }^{11}$

We sought to understand the perspectives of health professionals regarding AID by appraising their knowledge and perception on semen donation for artificial insemination. Data from this study may assist in formulating policies and guidelines on semen donation for artificial insemination which are evidenced based and tailored to the peculiarity of our community.

\section{METHODS}

This was a descriptive cross-sectional survey using a semi-structured questionnaire administered among the study population (health workers) at a health institution (Bowen university teaching hospital) in Southwest, Nigeria. The health institution is in a cosmopolitan city inhabited by the dominant three ethnic groups of Nigeria (Yoruba, Hausa and Igbos). The health institution has staff strength of 224 health workers made up of doctors and nurses. The study was carried out over a period of two months (March to April, 2018) with administration of semi-structured questionnaire.

\section{Inclusion criteria}

- Age above 18 years

- Respondents who gave their consent to participate in the study.

\section{Exclusion criteria}

- Respondents who decline to participate in the study.

\section{Selection of respondents}

One hundred and fifty-two health workers met the inclusion criteria and exclusion criterion.

\section{Ethical consideration}

Ethical approval for the study was obtained from the ethical review committee of the institution with ethical clearance registration number of NHREC/12/04/2012. Also, a written consent of each respondent was sought for before being enrolled into the study (Appendix). Participation in the study was voluntary and absolute confidentiality was employed regarding the data collected; questionnaires were made anonymous with the use of questionnaire identity numbers instead of respondents' names.

\section{Study instrument}

A semi-structured questionnaire of four sections was used for data collection (Appendix). Data collected were biodata, knowledge of Artificial insemination of donor semen (AID), perception of AID and willingness in donating semen for insemination. Responses to questions on knowledge and perception of AID were graded using a 5-point Likert scale while responses of male respondents to questions bothering on willingness in donating semen for insemination were graded with a 3-point scale of Yes, No, and I don't know.

Eight structured questions which bother on the definition, indications and usefulness of AID to achieve conception 
were used to assess each respondent's knowledge of AID (Appendix). The response to each question was scored with a score range of 1 to 5 which corresponded to the score allocated to each response using a 5-point Likert scale (Table 2). The summation of score from each question was used to determine the aggregate score of each respondent on knowledge of AID.

A score of at least 4 in each question (which corresponds to agreeing to the question) was considered a good knowledge of the question, thus an aggregate score $\geq 32$ from the 8 questions asked was considered to be good knowledge while aggregate score $<32$ was considered as poor knowledge of AID.

\section{Statistical analysis}

Data collected were analyzed using the Statistical Package for the Social Sciences (IBM Corp. Released 2012. IBM SPSS Statistics for Windows, Version 21.0. Armonk, NY: IBM Corp). Categorical data were summarized as frequencies, proportion and rates, while continuous data were summarized using mean, standard deviation, median and range. Inferential analysis/association of socio-demographic characteristics and the knowledge of respondents on Artificial insemination of donor semen (AID) were done with Pearson's chi-square at a level of significance of $<0.05$. Furthermore, multiple logistic regression was used to assess the relationship of the statistically significant associations between socio-demographic factors and respondents' knowledge of Artificial insemination of donor semen at a P-value $<0.05$.

\section{RESULTS}

One hundred and fifty-two respondents met the selection criteria and the questionnaires were administered to them of which 121 respondents completed the survey with a response rate of $79.6 \%$. The age range of the respondents was between 22 years to 45 years with a mean age of $27.58 \pm 5.5$ years.

Socio-demographic characteristics of the respondents which include age, gender, marital status, religion, occupation and level of education are depicted in Table 1. Many of the respondents are in the age group of 2630years of age $(49.6 \%)$ with a mean age of $27.58 \pm 5.5 y e a r s$. Sixty of the respondents were male (49.6\%) while $61(50.4 \%)$ were of female gender. Majority of the respondents are married (74.4\%). Also, majority of the respondents were of Christian religion $(93.4 \%)$ with only few respondents reported to be of Islamic faith $(6.6 \%)$; however, other religions were not represented in the study. Twenty-six $(21.5 \%)$ of the respondents were doctors and 95 (78.5\%) of the respondents were nurses. Almost all the respondents $(98.3 \%)$ had tertiary education.
Eighty-four of the respondents $(69.4 \%)$ demonstrated good knowledge of Artificial insemination of donor semen (AID) while 37 of the respondents (30.6\%) had poor knowledge (Table 2).

Table 1: Socio-demographic characteristics of respondents.

\begin{tabular}{|c|c|c|}
\hline Variables & Frequency $(n=121)$ & Percentage \\
\hline \multicolumn{3}{|l|}{ Age groups } \\
\hline $21-25$ & 11 & 9.1 \\
\hline $26-30$ & 60 & 49.6 \\
\hline $31-35$ & 19 & 15.7 \\
\hline $36-40$ & 19 & 15.7 \\
\hline$>40$ & 12 & 9.9 \\
\hline \multicolumn{3}{|c|}{ Mean \pm SD, 27.58 \pm 5.5years } \\
\hline \multicolumn{3}{|c|}{ Gender } \\
\hline Male & 60 & 49.6 \\
\hline Female & 61 & 50.4 \\
\hline \multicolumn{3}{|c|}{ Marital status } \\
\hline Single & 31 & 25.6 \\
\hline Married & 90 & 74.4 \\
\hline \multicolumn{3}{|l|}{ Religion } \\
\hline Christianity & 113 & 93.4 \\
\hline Islam & 8 & 6.6 \\
\hline \multicolumn{3}{|l|}{ Occupation } \\
\hline Doctor & 26 & 21.5 \\
\hline Nurse & 95 & 78.5 \\
\hline \multicolumn{3}{|c|}{ Level of education } \\
\hline Secondary & 2 & 1.7 \\
\hline Tertiary & 119 & 98.3 \\
\hline
\end{tabular}

Association between the age, gender, religion, level of education of the respondents and knowledge of respondents on AID were found not to be statistically significant at a P-value $<0.05$. However, cadre of health workers and marital status had statistically significant associations with the knowledge of respondents on AID at a P-value <0.05 (Table 3).

In the multiple logistic regression analysis of the sociodemographic characteristics and respondents knowledge of Artificial insemination of donor semen (AID), nurses are $25 \%$ as likely as doctors to have good knowledge of AID (OR: $0.253 ; 95 \%$ CI:0.074-0.861; $\rho=0.028$ ) while married respondents were 4 times more likely to have good knowledge of AID when compared to single respondents (OR:4.291; 95\% CI:1.720-10.703; $\rho=0.002$ ).

Responses of respondents on perceptions on Artificial insemination of donor semen are shown in Table 4. Eighty-six $(71.1 \%)$ of the respondents perceived AID could result into emotional issues in couples $(61.2 \%$ agreed and $9.9 \%$ strongly agreed). Also, 65(53.7\%) of the respondents perceived AID can affect couples' marriage sustainability (41.3\% agreed and 12.4 strongly agreed). Use of donated semen for pregnancy was perceived to lead to low self-esteem and depression in the 
man/husband by $86(71.1 \%)$ of the respondents and 77 $(63.7 \%)$ of the respondents agreed/strongly agreed on the fear of the donor showing up at the front door someday to claim parental right to the child conceived by AID.

Table 2: Knowledge of donor semen insemination $(n=121)$.

\begin{tabular}{|c|c|c|c|c|c|}
\hline Variables & $\begin{array}{l}\text { SD n (\%) } \\
1\end{array}$ & $\begin{array}{l}\mathrm{D} \text { n }(\%) \\
2\end{array}$ & $\begin{array}{l}\text { N n (\%) } \\
3\end{array}$ & $\begin{array}{l}\text { A n (\%) } \\
4\end{array}$ & $\begin{array}{l}\text { SA n } \\
(\%) 5\end{array}$ \\
\hline $\begin{array}{l}\text { Donor semen insemination involves use of donated } \\
\text { sperm from another man to achieve pregnancy in a } \\
\text { woman }\end{array}$ & $2(1.7)$ & $3(2.5)$ & $1(0.8)$ & $42(34.7)$ & $73(60.3)$ \\
\hline $\begin{array}{l}\text { Donor semen insemination is a form of assisted } \\
\text { reproductive technique }\end{array}$ & $2(1.7)$ & $2(1.7)$ & $0(0.0)$ & $39(32.2)$ & $78(64.5)$ \\
\hline $\begin{array}{l}\text { Donor semen insemination can be used to achieve } \\
\text { pregnancy in an infertile couple in which the man has } \\
\text { severe low sperm count }\end{array}$ & $2(1.7)$ & $6(5.0)$ & $2(1.7)$ & $40(33.1)$ & $71(58.7)$ \\
\hline $\begin{array}{l}\text { Donor semen insemination can be used to achieve } \\
\text { pregnancy in an infertile couple in which the man has no } \\
\text { sperm count }\end{array}$ & $6(5.0)$ & $9(7.4)$ & $5(4.1)$ & $39(32.2)$ & $62(51.2)$ \\
\hline $\begin{array}{l}\text { Donor semen insemination can be used to achieve } \\
\text { pregnancy in a single woman desirous of pregnancy }\end{array}$ & $6(5.0)$ & $6(5.0)$ & $9(7.4)$ & $50(41.3)$ & $50(41.3)$ \\
\hline $\begin{array}{l}\text { Donor semen insemination cannot be used to achieve } \\
\text { pregnancy in an infertile couple in which there is a } \\
\text { female cause to the infertility }\end{array}$ & $7(5.8)$ & $18(14.9)$ & $16(13.2)$ & 44 (36.4) & $36(29.7)$ \\
\hline $\begin{array}{l}\text { Donor semen insemination can be used to prevent } \\
\text { inheritance of genetic disease from a man to his } \\
\text { child/children }\end{array}$ & $11(9.1)$ & $15(12.4)$ & $19(15.7)$ & $47(38.8)$ & $29(23.9)$ \\
\hline $\begin{array}{l}\text { Couples/individual have the right to decide which } \\
\text { donor/sperm bank to use }\end{array}$ & $4(3.3)$ & $5(4.1)$ & $7(5.8)$ & $51(42.1)$ & $54(44.6)$ \\
\hline
\end{tabular}

$\uparrow$ SD- strongly disagree; D- disagree; N- neither agree or disagree; A- agree; SA- strongly agree.

Table 3: Association between socio-demographic characteristics and knowledge of respondents about semen donation.

\begin{tabular}{|c|c|c|c|c|}
\hline \multirow[t]{2}{*}{ Variables } & \multicolumn{3}{|c|}{ Knowledge of respondents } & \multirow[b]{2}{*}{$\rho$} \\
\hline & Poor (\%) & $\operatorname{Good}(\%)$ & $\chi^{2}$ & \\
\hline \multicolumn{5}{|l|}{ Age group } \\
\hline $21-25$ & $3(27.3)$ & $8(72.7)$ & & \\
\hline $26-30$ & $14(23.3)$ & 46 (76.7) & & \\
\hline $31-35$ & $6(31.6)$ & $13(68.4)$ & & \\
\hline $36-40$ & $9(47.4)$ & $10(52.6)$ & & \\
\hline$>40$ & $5(41.7)$ & $7(58.3)$ & 4.767 & 0.312 \\
\hline \multicolumn{5}{|l|}{ Gender } \\
\hline Male & $18(30.0)$ & $42(70.0)$ & & \\
\hline Female & $19(31.1)$ & $42(68.9)$ & 0.891 & 0.524 \\
\hline \multicolumn{5}{|c|}{ Marital status } \\
\hline Single & $16(51.6)$ & $15(48.4)$ & & \\
\hline Married & $21(23.6)$ & $69(76.4)$ & 8.687 & 0.003 \\
\hline \multicolumn{5}{|l|}{ Religion } \\
\hline Christianity & $33(29.2)$ & $80(70.8)$ & & \\
\hline Islam & $4(50.0)$ & $4(50.0)$ & 2.470 & 0.116 \\
\hline \multicolumn{5}{|l|}{ Occupation } \\
\hline Doctor & $4(15.4)$ & $22(84.6)$ & & \\
\hline Nurse & $33(34.7)$ & $62(65.3)$ & 3.969 & 0.046 \\
\hline \multicolumn{5}{|c|}{ Level of education } \\
\hline Secondary & $1(50.0)$ & $1(50.0)$ & & \\
\hline Tertiary & $36(30.3)$ & $83(69.7)$ & 0.361 & 0.538 \\
\hline
\end{tabular}


Table 4: Perception of respondents towards artificial insemination with donor semen $(\mathrm{n}=121)$.

\begin{tabular}{|llllll|}
\hline Variables & $\begin{array}{l}\text { Strongly } \\
\text { disagree }\end{array}$ & Disagree & $\begin{array}{l}\text { Neither agree } \\
\text { nor disagree }\end{array}$ & Agree & $\begin{array}{l}\text { Strongly } \\
\text { agree }\end{array}$ \\
\hline Use of donated semen for pregnancy is morally wrong & $30(24.8)$ & $50(41.3)$ & $27(22.3)$ & $9(7.4)$ & $5(4.1)$ \\
\hline $\begin{array}{l}\text { Use of donated semen for pregnancy is against my } \\
\text { culture }\end{array}$ & $22(18.2)$ & $37(30.6)$ & $29(24.0)$ & $27(22.3)$ & $6(5.0)$ \\
\hline $\begin{array}{l}\text { Use of donated semen for pregnancy is medically } \\
\text { unsafe with possible transmission of infections such } \\
\text { as HIV, hepatitis, CMV }\end{array}$ & $22(18.2)$ & $45(37.2)$ & $19(15.7)$ & $28(23.1)$ & $7(5.8)$ \\
\hline $\begin{array}{l}\text { Use of donated semen for pregnancy is against my } \\
\text { religious beliefs }\end{array}$ & $19(15.7)$ & $45(37.2)$ & $30(24.8)$ & $18(14.9)$ & $9(7.4)$ \\
\hline $\begin{array}{l}\text { Use of donated semen for pregnancy can result into } \\
\text { emotional issues in the couple }\end{array}$ & $9(7.4)$ & $8(6.6)$ & $18(14.9)$ & $74(61.2)$ & $12(9.9)$ \\
\hline $\begin{array}{l}\text { Use of donated semen for pregnancy can affect } \\
\text { marriage sustainability }\end{array}$ & $6(5.0)$ & $22(18.2)$ & $28(23.1)$ & $50(41.3)$ & $15(12.4)$ \\
\hline $\begin{array}{l}\text { Use of donated semen for pregnancy can lead to } \\
\text { paternity/ legal disputes }\end{array}$ & $7(5.8)$ & $21(17.4)$ & $16(13.2)$ & $59(48.8)$ & $18(14.9)$ \\
\hline $\begin{array}{l}\text { Use of donated semen for pregnancy can lead to low } \\
\text { self-esteem and depression in the man/husband }\end{array}$ & $7(5.8)$ & $10(8.3)$ & $18(14.9)$ & $64(52.9)$ & $22(18.2)$ \\
\hline $\begin{array}{l}\text { Fear of the donor showing up at the front door } \\
\text { someday to claim parental right to the child }\end{array}$ & $8(6.6)$ & $22(18.2)$ & $14(11.6)$ & $59(48.8)$ & $18(14.9)$ \\
\hline $\begin{array}{l}\text { Use of donated semen for pregnancy can lead to lack } \\
\text { of parental bond/ connection to the child especially } \\
\text { from the man }\end{array}$ & $19(15.7)$ & $29(24.0)$ & $19(15.7)$ & $45(37.2)$ & $9(7.4)$ \\
\hline $\begin{array}{l}\text { Child from a donated semen may be referred to as a } \\
\text { bastard }\end{array}$ & $21(17.4)$ & $36(29.8)$ & $20(16.5)$ & $35(28.9)$ & $9(7.4)$ \\
\hline $\begin{array}{l}\text { Adopting a child is a better option for an infertile } \\
\text { couple than donor semen insemination }\end{array}$ & $13(10.7)$ & $34(128.1)$ & $35(28.9)$ & $23(19.0)$ & $16(13.2)$ \\
\hline
\end{tabular}

Table 5: Willingness to donate semen for Artificial insemination by male respondents ( $\mathrm{n}=60$ ).

\begin{tabular}{|llll|}
\hline Variable & No (\%) & $\begin{array}{l}\text { Idon't } \\
\text { know (\%) }\end{array}$ & Yes (\%) \\
\hline Have you donated semen before? & $60(100.0)$ & $0(0.0)$ & $0(0.0)$ \\
\hline $\begin{array}{l}\text { Are you willing to donate your semen for an infertile couple to achieve } \\
\text { pregnancy? }\end{array}$ & $32(53.3)$ & $12(20.0)$ & $16(26.7)$ \\
\hline Are you willing to donate semen free without financial benefit? & $40(66.7)$ & $9(15.0)$ & $11(18.3)$ \\
\hline $\begin{array}{l}\text { If you are to donate semen, will you want your identity to be known by the } \\
\text { recipient couple? }\end{array}$ & $52(86.7)$ & $6(10.0)$ & $2(3.3)$ \\
\hline $\begin{array}{l}\text { If you are to donate semen, will you want to know the identity of the intended } \\
\text { recipient couple? }\end{array}$ & $39(65.0)$ & $3(5.0)$ & $18(30.0)$ \\
\hline $\begin{array}{l}\text { Semen donation is against by religious beliefs } \\
\text { Donation of sperm is a taboo in my culture }\end{array}$ & $22(36.7)$ & $23(38.3)$ & $15(25.0)$ \\
\hline $\begin{array}{l}\text { Not ready to donate because of fear of being screened for HIV or genetic } \\
\text { disorders }\end{array}$ & $43(71.7)$ & $3(5.0)$ & $14(23.3)$ \\
\hline $\begin{array}{l}\text { Not ready to donate because of fear of my semen being used for fetish things } \\
\text { or other than for insemination. }\end{array}$ & $37(61.7)$ & $8(13.3)$ & $15(25.0)$ \\
\hline
\end{tabular}

The male respondents' response to questions on willingness of semen donation was depicted in Table 5. None of the male respondents had donated semen in the past but $16(26.7 \%)$ of the male respondents $(n=60)$ may wish to donate semen for an infertile couple to achieve conception. Fifty-two $(86.7 \%)$ of the male respondents $(\mathrm{n}=60)$ would prefer to be an anonymous donor however,
$18(30 \%)$ of the male respondents $(n=60)$ desired to know the identity of the recipient couple if they had to donate semen.

\section{DISCUSSION}

Almost two-third $(68 \%)$ of the health workers in this study demonstrated a good knowledge of Artificial 
Insemination of Donor Semen (AID) as a form of assisted reproductive technique; however, of much concern was the a third of the study population (32\%) who demonstrated poor knowledge of AID (32\%). Consequently, health workers with such poor knowledge of AID are not likely to provide adequate and reliable information on AID as a form of assisted reproductive techniques to infertile couple who may require it.

Cadre of the health workers and their marital status influenced their knowledge of AID. Nurses were three times less likely to be have a good knowledge of AID when compared to the doctors (OR: 0.253; 95\% CI:0.074-0.861; $\rho=0.028)$ while married health workers were 4 times as likely as the unmarried health workers to have good knowledge of AID (OR:4.291; 95\% CI:1.720$10.703 ; \rho=0.002)$. Further explanation of these findings was beyond the scope of the study however; these may reflect the training undergone by each cadre of health workers and the likelihood of married people seeking more knowledge on infertility and options of management. These findings further reiterate the need to strengthen the capacity of other health workers with the knowledge of infertility and its several ways of management.

Psycho social issues and legal disputes which may likely arise from AID were some of the factors influencing perception of the respondents. In this study, more than half of the respondents agreed that AID could result into emotional issues in couples (71.1\%), affect couples' marriage sustainability $(53.7 \%)$, low self-esteem and depression in male partners $(71.1 \%)$, fear of donor claiming parental right to the child conceived through AID $(63.7 \%)$.

In some of the established donor programs, there are guidelines and laws that govern gametes donation, authorities that registers fertility clinics and sperm banks to ensure ethical practices and prevent gametes trafficking. ${ }^{12,13}$ An example of such regulating authority is the United Kingdom's Human Fertilization and Embryology Authority (HFEA) which makes policies and regulate assisted reproductive therapy in the UK. ${ }^{14}$ Legislation regulating gamete donation are likely to prevent possible legal dispute that may arise from AID.

Majority of the respondents do not perceive AID as morally wrong but cultural and religious beliefs affected the perception of AID in about one- third of the respondents in this study (Table 4); however, more worrisome was the perception of AID to be medically unsafe by more than a third of the study population who are essentially health workers/professional who are presumed to be knowledgeable in health conditions and should be a trusted source of health information to patients. ${ }^{15,16}$

A considerable number of respondents (44.6\%) believed there would be poor parental bond between a child conceived by AID and the parents; furthermore, perception of such child being referred to as bastard was high among the respondents. Thus, it is not surprising that a few of the respondents preferred child adoption to AID in infertile couple who may require assisted reproductive technique.

Practice of semen donation for artificial insemination was non-existent among the study population as none of the male respondents has ever donated semen for artificial insemination. This finding is not unexpected as more than half of the male respondents $(53.3 \%)$ are unwilling to donate semen, one-fifth $(20 \%)$ are undecided and just slightly above one fourth of them are willing to donate semen on request; however, majority of them will not be a volunteer donor which may be contrary to some established donor program guidelines for semen donation. According to the recommendations of American Society for Reproductive Medicine and Society for Assisted Reproductive Technology, monetary incentive should not be the primary motivation for sperm donation. However, donors can be compensated for their expenses and time expended on the process of donation. ${ }^{17}$ A paid donor, whose motivation is monetary incentive may not divulge the truth regarding his medical history when he is in the know that an unfavourable medical history may prevent his enrollment into donor program. ${ }^{18}$ Also, in the European Union report on the regulation of reproductive cell donation, non-remuneration for donation was advocated by majority of the members' state to prevent organ trading and trafficking. ${ }^{19}$

Subsequently, legislation prohibiting payment for semen donation in a society with less altruistic semen donors may experience reduction in semen donation; this was observed in Canada and mainland China where semen donation for monetary gain is illegal. ${ }^{12,20}$

There were concerns about semen donation which may have influence the high number of unwillingness to donate semen for artificial insemination. Such concerns included religious beliefs against semen donation (25\%), cultural belief with semen donation perceived as a taboo (21.7\%), fear of being screened for HIV and genetic disorder $(23.3 \%)$ and fear of donated semen being used for fetish things other than for insemination (25\%).

Majority of the respondents from this study $(86.7 \%)$ prefer to be an anonymous donor and a third desired to know the identity of the recipient couple (Table 5). Reasons for the anonymity in semen donation and desire in knowing the identity of the recipient couple were beyond the scope of this study. However, anonymity of donor varies in different donor programs depending on the laws regulating each donor programs. It is pertinent to know that over the years; the traditional practices of gamete donation anonymity are slowly changing as views about the interests and rights of children to know about their genetic parents evolves. ${ }^{17}$ For example, in the United Kingdom, donor anonymity was removed by 
legislation in 2005 which requires any donor of gametes or embryos used in the treatment of other people to agree to the disclosure of their identity to any offspring reaching the age of 18 . The legislation enables a donorconceived person on reaching the age 18 can request the identity of their donor from the registry of the regulatory authority (human fertilization and embryology authority). ${ }^{21}$

It is almost impossible to have a complete anonymity without any record of the donor in semen donor programs as the donor must divulge his medical and family history. Also, prospective donors usually undergo medical and laboratory evaluation for suitability for semen donation. ${ }^{7}$

Limitation of the study: it may be difficult to generalize the findings from this study as the study is not free from selection bias due to single institution chosen for the study population. However, the study may serve as a pilot study on knowledge and perception of donor semen insemination in Nigeria; and the willingness of Nigerian men in donating semen for artificial insemination. The findings demonstrated the need for population-based study to further understand the knowledge and perception on semen donation for artificial insemination in Nigeria.

\section{CONCLUSION}

Knowledge gap of AID as a form of assisted reproductive technique still exist among health workers in Nigeria. Nurses and unmarried health workers were found to be less likely to have adequate knowledge about AID when compared to doctors and married health workers respectively. Perception of AID by the health workers varied considerably but it was mostly influenced by psycho-social factors and perceived legal disputes on the child conceived through the process of AID. Willingness in semen donation for insemination was low and anonymity preferred by possible likely donors.

\section{Recommendations}

- To strengthen the capacity of health professionals with knowledge of infertility and its diverse options of management through provision of educational resources and support to health workers managing infertility

- Advocacy and re-orientation of health professional on AID as a form of ART. This may reform the longheld perceptions of AIDS mostly influenced by socio-cultural beliefs and perceived likely legal dispute about reproduction through the process of AID

- Development of a national guideline for the practice of semen donation and AID as a form of ART in Nigeria. Also, there is a need to have a legal backing for the use of AID as from of ART to address perceived and possible legal disputes which may arise from use of donor semen for reproduction.
Funding: No funding sources

Conflict of interest: None declared

Ethical approval: The study was approved by the Institutional Ethics Committee

\section{REFERENCES}

1. Oguntoyinbo AE, Amole AOD, Komolafe OF. Sonographic assessment of fallopian tube patency in the investigation of female infertility in Ilorin, Nigeria. Afr J Reprod Health. 2001;5:100-5.

2. Panti AA, Sununu YT. The profile of infertility in a teaching Hospital in North West Nigeria. Sahel Med J. 2014;17(1):7-11.

3. Inhorn MC. Global infertility and the globalization of new reproductive technologies: illustrations from Egypt. Soc Sci Med. 2003;56(9):1837-51.

4. Ikechebelu JI, Adinma JIB, Orie EF, Ikegwuonu SO. High prevalence of male infertility in southeastern Nigeria. J Obstet Gynaecol. 2003;23(6):657-9.

5. Owolabi AT, Fasubaa OB, Ogunniyi SO. Semen quality of male partners of infertile couples in Ile-Ife, Nigeria. Niger J Clin Pract. 2013;16(1):37-40.

6. Male factor infertility: Management approach. BMJ Best practices. Available at: http://bestpractice.bmj.com/best-practice/monograph /497/treatment/step-by-step.html. Accessed on April 6th, 2019.

7. Practice committees of the American Society for Reproductive medicine and the Society for Assisted Reproductive Technology. Recommendations for gamete and embryo donation: a committee opinion. Fertil Steril. 2013;9(1):47-62.e1.

8. Botchan A, Hauser R, Gamzu R, Yogev L, Paz G, Yavetz H. Results of 6139 artificial insemination cycles with donor spermatozoa. Hum Reprod. 2001;16(11):2298-304.

9. Strickler RC, Keller DW, Warren JC. Artificial insemination with fresh donor semen. N Engl J Med. 1975;293(17):848-53.

10. Ugwu EO, Odoh GU, Obi SN, Ezugwu FO. Acceptability of artificial donor insemination among infertile couples in Enugu, southeastern Nigeria. Int J Womens Health. 2014;6:201-5.

11. Gong D, Liu YL, Zheng Z, Tian YF, Li Z. An overview on ethical issues about sperm donation. Asian J Androl. 2009;11(6):645-52.

12. Ping $P$, Zhu WB, Zhang XZ. Sperm donation and its application in China: a 7-year multicenter retrospective study. Asian J Androl. 2011;13(4):6448.

13. Golombok S, Scott R, Appleby JB. Regulating Reproductive Donation. UK: Cambridge University Press; 2016.

14. Welcome to the HFEA, Human Fertilisation and Embryology Authority. Available at: https://www.hfea.gov.uk/. Accessed on April 13 $3^{\text {th }}$, 2019. 
15. Cutilli CC. Seeking health information: what sources do your patients use? Orthop Nurs. 2010;29(3):2149.

16. Hesse BW, Nelson DE, Kreps GL. Trust and sources of health information: the impact of the Internet and its implications for health care providers: findings from the first Health Information National Trends Survey. Arch Intern Med. 2005;165(22):2618-24.

17. Medicine EC of the AS for R. Interests, obligations, and rights in gamete donation: a committee opinion. Fertil Steril. 2014;102(3):675-81.

18. Hummel WP, Talbert LM. Current management of a donor insemination program. Fertil Steril. 1989;51(6):919-30.

19. Report on the regulation of reproductive cell donation in the European Union. 2006. Available at: https://ec.europa.eu/health/ph_threats/human_substa nce/documents/tissues_frep_en.pdf. Accessed April 8th, 2019.
20. O’Reilly D, Bowen JM, Perampaladas K, Qureshi R, Xie F, Hughes E. Feasibility of an altruistic sperm donation program in Canada: results from a population-based model. Reprod Health. 2017;14(1):8.

21. Frith L, Blyth E, Farrand A. UK gamete donors' reflections on the removal of anonymity: implications for recruitment. Hum Reprod. 2007;22(6):1675-80.

Cite this article as: Abiola OO, Ajao AE, Ogunlaja OA, Adeoye SO, Ojo AA. Perspectives of health care professionals on artificial insemination of donor semen: appraising their knowledge and perceptions: a single institution study in Nigeria. Int J Reprod Contracept Obstet Gynecol 2019;8:2959-68. 


\section{Appendix}

Questionnaire on artificial insemination of donor semen: knowledge, perception and willingness of semen donation

\section{Consent}

We desire that you give us your consent to participate in this study. All information given in this questionnaire shall be treated as confidential information.

Kindly tick as appropriate:
Agree

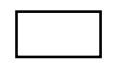
Disagree

If you consented to participate in this study, kindly fill the attached questionnaire

Thank you.

\section{(A) BIODATA:}

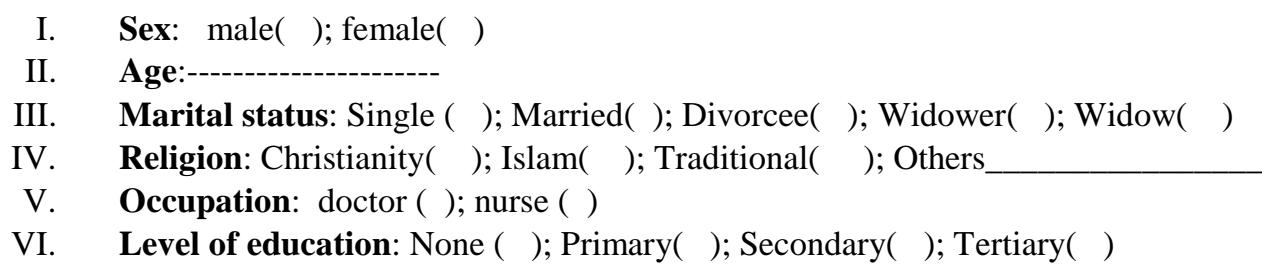

(B) AWARENESS:

\section{Kindly tick as appropriate}

\begin{tabular}{|c|c|c|c|c|c|c|}
\hline & & $\begin{array}{l}\text { Strongly } \\
\text { disagree } \\
\text { (1) }\end{array}$ & $\begin{array}{l}\text { Disagree } \\
\text { (2) }\end{array}$ & $\begin{array}{l}\text { Neither } \\
\text { agree nor } \\
\text { disagree (3) }\end{array}$ & $\begin{array}{l}\text { Agree } \\
\text { (4) }\end{array}$ & $\begin{array}{l}\text { Strongly } \\
\text { Agree (5) }\end{array}$ \\
\hline 1 & $\begin{array}{l}\text { Donor semen insemination involves use of donated } \\
\text { sperm from another man to achieve pregnancy in a } \\
\text { woman }\end{array}$ & & & & & \\
\hline 2 & $\begin{array}{l}\text { Donor semen insemination is a form of assisted } \\
\text { reproductive technique }\end{array}$ & & & & & \\
\hline 3 & $\begin{array}{l}\text { Donor semen insemination can be used to achieve } \\
\text { pregnancy in an infertile couple in which the man } \\
\text { has severe low sperm count }\end{array}$ & & & & & \\
\hline 4 & $\begin{array}{l}\text { Donor semen insemination can be used to achieve } \\
\text { pregnancy in an infertile couple in which the man } \\
\text { has no sperm count }\end{array}$ & & & & & \\
\hline 5 & $\begin{array}{l}\text { Donor semen insemination can be used to achieve } \\
\text { pregnancy in a single woman desirous of pregnancy }\end{array}$ & & & & & \\
\hline 6 & $\begin{array}{l}\text { Donor semen insemination cannot be used to } \\
\text { achieve pregnancy in an infertile couple in which } \\
\text { there is a female cause to the infertility }\end{array}$ & & & & & \\
\hline 7 & $\begin{array}{l}\text { Donor semen insemination can be used to prevent } \\
\text { inheritance of genetic disease from a man to his } \\
\text { child/children }\end{array}$ & & & & & \\
\hline 8 & $\begin{array}{l}\text { Couples/individual have the right to decide which } \\
\text { donor/sperm bank to use }\end{array}$ & & & & & \\
\hline
\end{tabular}


(C) PERCEPTION:

\begin{tabular}{|c|c|c|c|c|c|c|}
\hline & & $\begin{array}{l}\text { Strongly } \\
\text { disagree } \\
\text { (1) }\end{array}$ & $\begin{array}{l}\text { Disagree } \\
\text { (2) }\end{array}$ & $\begin{array}{l}\text { Neither } \\
\text { agree nor } \\
\text { disagree } \\
\text { (3) }\end{array}$ & Agree (4) & $\begin{array}{l}\text { Strongly } \\
\text { Agree (5) }\end{array}$ \\
\hline 1 & $\begin{array}{l}\text { Use of donated semen for pregnancy is morally } \\
\text { wrong }\end{array}$ & & & & & \\
\hline 2 & $\begin{array}{l}\text { Use of donated semen for pregnancy is against } \\
\text { my culture }\end{array}$ & & & & & \\
\hline 3 & $\begin{array}{l}\text { Use of donated semen for pregnancy is } \\
\text { medically unsafe with possible transmission of } \\
\text { infections such as HIV, hepatitis, CMV }\end{array}$ & & & & & \\
\hline 4 & $\begin{array}{l}\text { Use of donated semen for pregnancy is against } \\
\text { my religious beliefs }\end{array}$ & & & & & \\
\hline 5 & $\begin{array}{l}\text { Use of donated semen for pregnancy can result } \\
\text { into emotional issues in the couple }\end{array}$ & & & & & \\
\hline 6 & $\begin{array}{l}\text { Use of donated semen for pregnancy can affect } \\
\text { marriage sustainability }\end{array}$ & & & & & \\
\hline 7 & $\begin{array}{l}\text { Use of donated semen for pregnancy can lead to } \\
\text { paternity/ legal disputes }\end{array}$ & & & & & \\
\hline 8 & $\begin{array}{l}\text { Use of donated semen for pregnancy can lead to } \\
\text { low self-esteem and depression in the } \\
\text { man/husband }\end{array}$ & & & & & \\
\hline 9 & $\begin{array}{l}\text { Fear of the donor showing up at the front door } \\
\text { someday to claim parental right to the child }\end{array}$ & & & & & \\
\hline 10 & $\begin{array}{l}\text { Use of donated semen for pregnancy can lead to } \\
\text { lack of parental bond/ connection to the child } \\
\text { especially from the man }\end{array}$ & & & & & \\
\hline 11 & $\begin{array}{l}\text { Child from a donated semen may be referred to } \\
\text { as a bastard }\end{array}$ & & & & & \\
\hline 12 & $\begin{array}{l}\text { Adopting a child is a better option for an infertile } \\
\text { couple than donor semen insemination }\end{array}$ & & & & & \\
\hline
\end{tabular}

(D) WILLINGNESS TO DONATE SEMEN BY MEN (Tick appropriately if you are a man):

\begin{tabular}{|c|c|c|c|c|}
\hline & & No (1) & $\begin{array}{l}\text { I don't } \\
\text { know (2) }\end{array}$ & Yes (3) \\
\hline 1 & Have you donated semen before? & & & \\
\hline 2 & $\begin{array}{l}\text { Are you willing to donate your semen to infertile couple to achieve } \\
\text { pregnancy? }\end{array}$ & & & \\
\hline 3 & Are you willing to donate semen free without financial benefit? & & & \\
\hline 4 & $\begin{array}{l}\text { If you are to donate semen, will you want your identity to be known by } \\
\text { the recipient couple? }\end{array}$ & & & \\
\hline 5 & $\begin{array}{l}\text { If you are to donate semen, will you want to know the identity of the } \\
\text { intended recipient couple? }\end{array}$ & & & \\
\hline 6 & Semen donation is against by religious beliefs & & & \\
\hline 7 & Donation of sperm is a taboo in my culture & & & \\
\hline 8 & $\begin{array}{l}\text { Not ready to donate because of fear of being screened for HIV or } \\
\text { genetic disorders }\end{array}$ & & & \\
\hline 9 & $\begin{array}{l}\text { Not ready to donate because of fear of my semen being used for fetish } \\
\text { things or other than for insemination. }\end{array}$ & & & \\
\hline
\end{tabular}

